Introduction

Rebecka Taves Sheffield and Nicholas Giguère

\begin{abstract}
In their introduction to a special issue of the Papers of the Bibliographical Society of Canada, co-editors Rebecka Taves Sheffield and Nicholas Giguère provide a brief historical overview of the emergence of an LGBTQ+ press in Canada, and describe how the history of LGBTQ+ print culture in Canada is inextricably intertwined with the country's history of media censorship, which has been often used to exclude LGBTQ+ people from public spaces. Sheffield and Giguère then summarize the articles, note, and review essay included in the special journal issue and describe how, on a whole, the contributors' research sheds new light on the relationship between LGBTQ+ print media and the communities that it has both served and helped to create, despite persistent censorship.
\end{abstract}

\title{
Résumé
}

Dans l'introduction d'un numéro spécial des Cahiers de la Société bibliographique du Canada, les co-rédacteurs Rebecka Taves Sheffield et Nicholas Giguère donnent un aperçu historique de l'émergence d'une presse LGBTQ+ canadienne et décrivent comment l'histoire de la culture de l'imprimé LGBTQ+ au Canada est inextricablement liée à l'histoire de la censure des médias au pays, ayant souvent été utilisée pour exclure les personnes LGBTQ+ des espaces publics. Ensuite, ils résument les articles, la note, et l'essai critique inclus dans le numéro spécial de la revue et décrivent comment, dans l'ensemble, les recherches des contributeurs jettent une nouvelle lumière sur la relation entre la presse écrite LGBTQ+ et les communautés qu'elle a servi et aidé à créer malgré une censure persistante.

The history of LGBTQ+ print culture in Canada is inextricably intertwined with the country's history of media censorship, which has been often used to exclude LGBTQ+ people from public spaces. In 
the mid-I970s, for example, at the height of gay liberation activism, the Toronto police morality squad visited the offices of newsmagazine The Body Politic after the publishers ran a cartoon by Rand Holmes depicting an act of fellatio. ${ }^{\mathrm{I}}$ As the newsmagazine of record for Canada's gay liberation movement, The Body Politic maintained a readership that extended well beyond national borders. The message from police was clear: refrain from publishing provocative or explicit sexual content or risk legal entanglements. Nevertheless, incensed by the increased police scrutiny, members of the newsmagazine collective continued to operate on the edge of social acceptability. In early 1978, police raided the publication's offices in response to complaints about a 1977 article by Gerald Hannon titled, "Men Loving Boys Loving Men." Criminal charges were laid against three employees of the publisher for possession of obscene material for distribution (Section I59 of the Criminal Code) and "use of the mails for the purpose of transmitting indecent, immoral or scurrilous materials" (Section I64). Given the newsmagazine's broad reach, the raid and subsequent arrests sparked international protest, including one organized by Harvey Milk at the Canadian consulate in San Francisco. After two trials, the newsmagazine and its three officers were ultimately acquitted. The case would help modernize the country's restrictive postal laws.

LGBTQ+ print media was once again at the centre of a prolonged legal fight between Vancouver's Little Sister's Book and Art Emporium and the Canada Border Services Agency. ${ }^{2}$ Owners of the bookstore, which opened in 1983 , noted that any material imported from the United States was routinely seized at the border. When destined for other mainstream retailers, however, the same materials were delivered without delay. Despite the anti-discrimination protections outlined in the Charter of Rights and Freedoms, material destined for the LGBTQ+ bookstore continued to face systematic targeting by Canadian border security personnel. Little Sister's filed a claim against the federal government in 1990, and its case was heard in October 1994. In January 1996, the trial concluded in favour of the plaintiffs and the court agreed that Little Sister's had experienced discrimination on the part of the Customs Mail Centre. On appeal, the case was heard again in 2000 by the Supreme Court of Canada, which found

I Jaime Bradburn, "Historicist: I Sing The Body Politic," Torontoist, I4 February 2015, https://torontoist.com/2015/02/historicist-i-sing-the-body-politic/.

2 Maryse Zeidler, "25 years ago, this LGBT landmark in Vancouver took on 'big brother' and won," CBC News, 20 October 2019, https://www.cbc.ca/news/ canada/british-columbia/little-sisters-cbsa-challenge-I. 5325456 . 
that, although Customs had targeted shipments to the bookstore and violated Section 2 of the Charter, it was nonetheless justified in doing so under Section I. The previous ruling was overturned based on the established legal power of Canada Customs to seize anything that sufficiently offends their sensibilities. While the cases did establish that the onus for proving that material is obscene lies with Canada Customs, it was also a chilling reminder to LGBTQ+ Canadians that print material by, for, and about them remained under threat.

Today, twenty years after the Little Sister's decision, this special issue reflects on the relationship between LGBTQ+ print media and the communities that it has both served and helped to create, despite persistent censorship. We know that likely the earliest LGBTQ+ publication, a mimeographed magazine called Les Mouches Fantastiques, was launched in 1918 by Montreal writers Elsa Gidlow and Roswell George Mills. As Andrew Stewart explains in his article "A Journal for Manly Culture: An Exploration of The World's First Gay Periodical," the turn of the century was a critical period for homosexuals who were just beginning to build communities around the idea of a sexual identity. This overview of the first known homosexual periodical, Der Eigene (1896-1933), urges scholars to consider how and why this magazine has been mostly overlooked by scholars and why it deserves further consideration. Noah Duranseuad's review essay also describes some of the early community-building activities that are celebrated in the exhibition $A$ Queer Century, I860-1960.

The emergence of a gay press in the postwar years marked another turn in how LGBTQ+ print media is produced and distributed, and for whom it is intended. In particular, book publishers took on more risks, either including more explicit homosexual content in anthologies or publishing monographs with homosexual or transgender characters. In "L'âne de Carpizan ou l'évêque volant de Raymond Goulet," Alexis Lacasse, Julien Vallières, and Jasmin Miville-Allard discuss the production, distribution, and reception of the first novel with a transgender protagonist to be published in Quebec. Printing technologies also improved during these crucial years, making it easier and more cost-effective to print small-run periodicals. Publishing for an LGBTQ+ market also became a profitable activity. In 1964, for example, three Toronto men began publishing Gay, the first explicitly homosexual magazine in Canada. ${ }^{3}$

3 Donald W. McLeod, A Brief History of Gay: Canada's First Gay Tabloid, 1964-1966 (Toronto: Homewood Books, 2003). 
A commercial venture, Gay included articles, letters to the editor, a diary, gossip columns, and personal ads, as well as fiction and poetry. The magazine sold roughly eight thousand copies of its spring 1965 issue before criminal charges were laid against one of its three publishers and the project was shuttered. Around this same time, homophile groups, such as Vancouver's Association for Social Knowledge (ASK), began printing newsletters for members using some of the new printing technologies available in postwar Canada. This English tradition of periodical and organizational newsletters was also prominent in French Quebec, where André Dion produced Le Tiers (197I-1972) and the Association pour les droits des gai(e)s du Quebec (ADGQ) published Le Berdache (1979-82). These publications tell compelling stories about LGBTQ+ people.

The proliferation of reprographic and computer technologies in the I990s facilitated yet another wave of LGBTQ+ print media. New print formats coincided with a broadening of identities loosely (and often awkwardly) described with the alphabet of LGBT and, more recently, LGBTTQQIAAP (lesbian, gay, bisexual, transgender, transsexual, queer, questioning, intersex, asexual, ally, pansexual). Emerging in the wake of the AIDS crisis, many queer communities used a combination of creative arts and photocopiers to grow a strong tradition of zine publishing which could be done outside of mainstream publishing and distribution systems - and with a barebones budget. As Sidney Cunningham discusses in "Subscribing to gendertrash: The Radical Subcultural Transmissions of Toronto's Original "TransZine," this new method of publishing gave voice to genderqueers and trans people outside of the lesbian and gay press, which tended to prioritize homocentric identities. In addition, more accessible printing technologies contributed to another kind of LGBTQ+ print media: handbills, posters, pamphlets, and other paper materials used to communicate outward to an increasing number of communities with relationships to the LGBTQ+ identity. In "Sticky: The Vazaleen Posters," Mark Clintberg draws from critical and queer theory to reflect on a poster series created by artist Michael Comeau to promote a party series organized by Toronto visual artist Will Munro.

As contributors to this special issue demonstrate, the rise of LGBTQ+ print media coincides with the mobilization of homophile movements, gay and lesbian rights movements, and queer and trans movements within and outside of Canada. For more than a century, LGBTQ+ print media has been produced by these movements, reflecting their histories, their evolutions, and their upheavals. This 
material is now part of academic study as primary sources driving new methodological and philosophical research on LGBTQ+ history. Rounding out this special issue is Donald McLeod's "From Paper, to Microform, to Digital? Serials at the ArQuives: Canada's LGBTQ2+ Archives." This essay not only provides insight into how so much of this print media, despite its persistent suppression by the state, has been carefully preserved by the ArQuives: Canada's LGBTQ2+ Archives, but also offers a glimpse of one possible future for the bibliographical study of this material. That future is digital.

In this present moment of digitization and digitalization of media, we stop to consider the history of LGBTQ+ print media as artefacts with specific bibliographical contexts. How has this material been shaped by social dimensions? How has this material been shaped by LGBTQ+ sensibilities at particular times and places? To what extent do these books, pamphlets, periodicals, posters, and ephemera reflect LGBTQ+ histories? What can these materials tell us about the time in which they were produced and what can they say about the present and future for LGBTQ+ people? These are just a few of the larger questions that guided us in the selection of papers for this special issue. Although these studies cannot possibly represent the totality of LGBTQ+ print culture in Canada, they illustrate the diversity and complexity of LGBTQ+ histories and should serve as catalysts for further study.

We sincerely hope this special issue will represent a milestone in the history of LGBTQ+ studies, and in the history of publishing more generally. Like the American novelist and playwright Larry Kramer, we wish that more people would write about gay history. ${ }^{4}$ This includes LGBTQ+ print media and all of those other traces of community, here and elsewhere.

\section{Author Biographies}

Rebecka Taves Sheffield (she/her) is an archivist and archival educator based in Hamilton, Ontario. She has taught in graduate programs at Simmons University (Boston) and the University of Toronto. Presently, she is a senior policy advisor for the Archives of

4 Larry Kramer, "Larry Kramer Wishes More People Wrote About Gay History," New York Times, I6 January 2020, https://www.nytimes.com/2020/or/16/books/ review/larry-kramer-by-the-book-interview.html. 
Ontario, where she works on digital recordkeeping strategy. Rebecka previously served as the Executive Director for the ArQuives, where she spent the better part of a decade learning as much as possible about Canada's LGBTQ2+ histories. This experience is the subject of her recent book, Documenting Rebellions: A Story of Four Lesbian and Gay Archives in Queer Times (Litwin Books). Rebecka has studied sociology, gender studies, publishing, and archives. She completed a $\mathrm{PhD}$ in information studies and sexual diversity studies at the University of Toronto.

Docteur en études françaises de l'Université de Sherbrooke, Nicholas Giguère a soutenu une thèse sur l'évolution des périodiques gais au Québec. Membre du Conseil de la Société bibliographique du Canada et rédacteur en chef adjoint des Cahiers de la Société bibliographique du Canada/Papers of the Bibliographical Society of Canada de 2016 à 2020, il est l'auteur d'articles et de comptes rendus, parus notamment dans Mémoires du livre/Studies in Book Culture, Documentation et bibliothèques, Quebec Studies et Revue critique de fixxion française contemporaine. Il a également collaboré à des projets de recherche d'envergure, dont le Dictionnaire des auvres littéraires du Québec, le Dictionnaire des intellectuels.les au Québec et le Dictionnaire historique des gens du livre au Québec. Chargé de cours à l'Université de Sherbrooke, il donne des cours sur la théorie queer, la sociologie de la littérature et l'histoire du livre au Québec. 